\title{
Identification of a Set of Up-regulated Genes due to Infection by Colletotrichum musae in a Dessert Banana Cultivar, Moderately- Resistant to Anthracnose
}

\author{
U.M. Aruna Kumara, N.C.Y. Jayasundara ${ }^{1}$ and D.M. De Costa ${ }^{1 *}$ \\ Postgraduate Institute of Agriculture \\ University of Peradeniya \\ Sri Lanka
}

\begin{abstract}
Understanding the mechanisms of host plant resistance at molecular level is useful towards designing effective disease management programmes against infections of plant pathogens. The present study was conducted to identify host plant genes expressed in response to infection by Colletotrichum musae using a moderately-resistant cultivar of banana (Seenikesel) to anthracnose. The expression profile of a selected defense-related gene over the infection process in the banana cultivar Seenikesel was also determined. Identification of genes was done by differential hybridization of a cDNA library constructed from peel tissues of banana inoculated with $\underline{C}$. musae. Up-regulated genes due to $\underline{C}$. musae infection were predicted through DNA homology search. Among the identified putative defense related genes, expression profile of Germin-like protein was studied by relative RT$P C R$ over a period of $144 \mathrm{~h}$ after inoculation. The set of up-regulated gene transcripts identified in the present study were responsible for plant defense, stress response, growth, development, protein synthesis, protein folding and stabilization. Expression of Germin-like protein gene homologue was comparatively high at the late phase of inoculation (96 h after inoculation) of $\underline{\text { C. }}$ musae in banana cultivar Seenikesel.
\end{abstract}

Keywords: cDNA library, differential hybridization, Germin-like protein, relative RT-PCR

\section{INTRODUCTION}

Banana including plantain (Musa spp.) have been ranked as the fourth important food crop and the second important fruit crop in the world (FAO Stat, 2007; Lassois et al., 2010). In Sri Lanka, banana and plantains are widely consumed as a dessert fruit and a vegetable fruit, respectively. Although it is predominantly produced for the local market of Sri Lanka, banana has been identified as a crop with a high potential to contribute to the national economy through export earnings (De Costa \& Kalpage, 2006).

Bananas are subjected to numerous infectious diseases which can lead to severe pre- and postharvest losses in terms of quality and quantity (Ma et al., 2009). Anthracnose caused by Colletotrichum musae (Berk. and Curt.) is one of the most important diseases infecting banana at postharvest stage (Abd-Elsalam et al., 2010; Wardlaw, 1934). Symptoms of anthracnose on banana occur as peel blemishes and black or brown sunken spots of various

\footnotetext{
1 Department of Agricultural Biology, Faculty of Agriculture, University of Peradeniya, Sri Lanka

* Corresponding author: devikacos@yahoo.com
} 
sizes on fruits. The symptoms initially develop on the fruit peel and later can get extended into the fruit pulp of ripe banana. However, previous investigations have revealed that the dessert type banana cultivars available in Sri Lanka have a variation in the degree of symptom development (De Costa et al., Unpublished data). This variation could be due to incompatibilities between the host and the pathogen, which cause a failure in the pathogen to become successful. There could be three reasons for the failure of the pathogen, i.e. the plant is unable to fulfill the niche requirements of the potential pathogen hence it is a non-host, the plant possesses preformed structural or biochemical defense mechanisms that prevent colonization of the pathogen (Shibuya \& Minami, 2001) or plant defense mechanisms are activated upon the recognition of the pathogen to contain infection (Hammond-Kosack \& Jones, 1996). A detailed understanding of the basis of host resistance at genetic and molecular level would be an essential initial step towards effective disease management and crop improvement against plant pathogens.

The objectives of the present study were to identify genes expressed in host plant in response to infection by Colletotrichum musae using a moderately-resistant cultivar of banana and to determine the expression profile of a selected defense-related gene over the infection process in the banana cultivar moderately-resistant to anthracnose development.

\section{MATERIALS AND METHODS}

\section{Collection of banana fruits and inoculation by $C$. musae}

Well-grown and fully-matured, (i.e. at Maturity Index 1 according to the standard charts by Kader, 2005) banana bunches of cultivar Seenikesel (ABB), which were free from external blemishes were collected randomly from three semi-commercial plantations in Kandy, Sri Lanka. In the field, the banana bunches were covered with plastic sleeves to avoid natural inoculation of $C$. musae. The fruits were detached from different hands or bunches were randomly assigned to two sets of treatments, namely 'inoculated' and 'non-inoculated' (control). Peel of banana fruits of 'inoculated' sample were injected with an aliquot of $10 \mu \mathrm{l}$ $\left(1 \mathrm{x} 10^{5}\right.$ spores $\left.\mathrm{ml}^{-1}\right)$ of $C$. musae spore suspension. Spore suspension of $C$. musae was prepared by vortexing spore masses obtained from a pure culture of the fungus grown on PDA and enumerating the spore concentration by a haemocytometer. Two spots per fruit were inoculated in thirty fruits and inoculated fruits were incubated in incubation chamber at room temperature $\left(28{ }^{\circ} \mathrm{C}\right)$ and $90 \% \mathrm{RH}$. The banana fruits kept as 'control' were inoculated with $10 \mu \mathrm{l}$ of sterilized distilled water and incubated as given above.

\section{Preparation of cDNA library}

\section{Harvesting of the banana fruit peel tissues}

Peel tissues were collected from the immediate surroundings of the point of inoculation one hour before inoculation with $C$. musae spores suspension. Similarly, peel tissues were collected from the inoculated fruits $1 \mathrm{~h}, 24 \mathrm{~h}, 48 \mathrm{~h}, 96 \mathrm{~h}, 144 \mathrm{~h}$, and $192 \mathrm{~h}$ after the inoculation. Three fruits were used at each harvesting time. Peel tissues were collected at different time intervals before and after inoculation of $C$. musae to determine the sequence of gene expression along different time intervals, just before and also from the onset of inoculation till symptoms were developed. Peel tissues collected at different time intervals were ground separately into a fine powder, with an adequate amount of liquid nitrogen in a 
$0.1 \%$ Diethyl-Phyrocarbonate (DEPC) treated motor and pestle and stored at $-80{ }^{\circ} \mathrm{C}$ until further use.

\section{Construction of cDNA library}

Total RNA was extracted separately from peel tissues of banana collected at different time intervals (i.e. $1 \mathrm{~h}$ before inoculation and $1 \mathrm{~h}, 24 \mathrm{~h}, 48 \mathrm{~h}, 96 \mathrm{~h}$ and $144 \mathrm{~h}$ and $192 \mathrm{~h}$ after inoculation of $C$. musae) using the method as follows. Extraction buffer contained $100 \mathrm{mM}$ Tris-Borate ( $\mathrm{pH}$ 8.2), $1.4 \mathrm{M} \mathrm{NaCl}, 20 \mathrm{mM}$ EDTA, 2\% (w/v) CTAB and $0.1 \% \beta$ mercaptoethanol. $0.1 \% \beta$ mercaptoethanol was added into the extraction buffer prior to the pre-warming of the buffer at $65{ }^{\circ} \mathrm{C}$ for $30 \mathrm{~min}$. An aliquot of $1 \mathrm{ml}$ of pre-warmed extraction buffer was added to each of the eppendorf tube containing powdered banana peel tissues, mixed thoroughly by vortexing and incubated at $65{ }^{\circ} \mathrm{C}$ for one hour. Samples were cooled to room temperature $\left(28{ }^{\circ} \mathrm{C}\right)$ and centrifuged at $12000 \mathrm{rpm}$ for $15 \mathrm{~min}$ at room temperature. The supernatant was collected into new eppendorf and extracted twice with chloroform:isoamyl alcohol (24:1). After centrifuging at $12000 \mathrm{rpm}$ for $15 \mathrm{~min}$ at room temperature, the supernatant was collected into new eppendorf tube and mixed with $10 \mathrm{M} \mathrm{LiCl}$ to a final concentration of $3 \mathrm{M}$. Then, the content was incubated overnight at $4{ }^{\circ} \mathrm{C}$ to precipitate total cellular RNA which was recovered by centrifuging at $14000 \mathrm{rpm}$ for $20 \mathrm{~min}$ at $4{ }^{\circ} \mathrm{C}$. The supernatant was decanted carefully and the pellet was dissolved in $500 \mu 1$ of DEPC treated water and extracted thrice with water saturated phenol, phenol: chloroform (1:1) and chloroform:isoamyl alcohol (24:1) respectively. The supernatant was then mixed with 1/30 volume of $3 \mathrm{M}$ sodium acetate ( $\mathrm{pH}$ 5.2) and 0.1 volume of absolute alcohol, and kept on ice for $30 \mathrm{~min}$ before centrifuging at $14000 \mathrm{rpm}$ for $25 \mathrm{~min}$ at $4{ }^{\circ} \mathrm{C}$. The supernatant was collected carefully without disturbing the white jelly like precipitate, and mixed with $3 \mathrm{M}$ sodium acetate ( $\mathrm{pH} 5.2$ ) to a final concentration of $0.3 \mathrm{M}$ and $3 \mathrm{x}$ volume of absolute alcohol. The mixture was incubated at $-80{ }^{\circ} \mathrm{C}$ overnight and RNA was recovered by centrifuging at $14000 \mathrm{rpm}$ for $20 \mathrm{~min}$. at $4{ }^{\circ} \mathrm{C}$. The RNA was rinsed with $70 \%$ ethanol and then recovered by centrifuging at $10000 \mathrm{rpm} 5 \mathrm{~min}$ at $4{ }^{\circ} \mathrm{C}$. Ethanol was removed by air drying. Then the pellet of RNA was dissolved in $10 \mu \mathrm{l}$ of DEPC treated water and was treated with DNAse $(1 \mathrm{u} / \mu 1)$ (Promega, RQ-1, DNAse).

Dynal beads and the paramagnetic particle technique (Dynal Biotech ASA, Norway) was used to extract mRNA from the total RNA samples. Those mRNA obtained from different time intervals after inoculation of the pathogen were pooled together and used for cDNA library construction. Pooling of mRNA was done to collect mRNA transcripts covering a range of time interval starting immediately after inoculation until a later stage of the

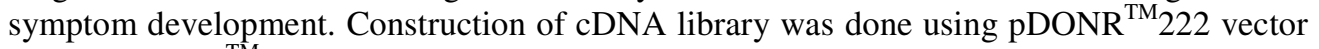
of CloneMiner ${ }^{\mathrm{TM}}$ cDNA library construction kit (Catalog No. 18249-029, Invitrogen, USA) based on Gateway ${ }^{\mathrm{R}}$ technology.,

\section{Obtaining of cDNA colonies}

After electroporation to E. coli host cells (ElectroMAX ${ }^{\mathrm{TM}}$ DH10B), $25 \mu \mathrm{l}$ of the cDNA library was diluted with $175 \mu$ l of sterilized distilled water and plated on LB agar medium supplemented with Kanamycin $(50 \mu \mathrm{g} / \mathrm{ml})$ and incubated at $37{ }^{\circ} \mathrm{C}$ for overnight. Wellisolated single colonies were transferred on to a grid pattern on LB agar plate supplemented with Kanamycin $(50 \mu \mathrm{g} / \mathrm{ml})$. Each clone was designated with a number and incubated at 37 ${ }^{0} \mathrm{C}$ overnight. 


\section{Preparation of colony blots}

Pieces of nylon membranes (Amersham Hybond $\mathrm{N}^{+}$, GE Healthcare,UK) were laid on LB solid medium supplemented with Kanamycin $(50 \mu \mathrm{g} / \mathrm{ml})$ under aseptic conditions. A set of cDNA clones (i.e. 384 cDNA clones) were arrayed on four pieces of sterilized Nylon membranes and incubated overnight at $37{ }^{\circ} \mathrm{C}$.

\section{Differential hybridization}

Differential hybridization was done using Digoxygenin-labeled total cDNA probes to determine up- and down-regulated genes in cultivar Seenikehel due to C. musae infection. Two different probes were prepared from total cDNA synthesized from the peel tissues of banana inoculated with C. musae (i.e. Treated probe) and non-inoculated with C. musae (i.e. Control probe). Labeling of the total cDNA was done according to instruction of the manufacturer (Dig DNA labeling and detection kit - Catalog No. 11093657 910, Roche, Germany).

Detection of the signals after nucleic acid hybridization was done by chemiluminesence method on X-ray films (DIG Luminescent Detection Kit-Cat No.11 363514 910, Roche, Germany). cDNA clones with up and down-regulated genes were identified by comparing the signal intensity developed on X-ray films. Briefly, cDNA clones which were having an up-regulated gene in response to $C$. musae inoculation were shown higher signal intensity when hybridized with the treated probe (i.e. prepared from banana peel tissues inoculated with $C$. musae) than the signal intensity given by a control probe (i.e. non-inoculated). In contrast, cDNA clones which were having down-regulated genes in response to C. musae inoculation were shown lower signal intensity when hybridized with the treated probe than the signal intensity given by that hybridized with control probe.

\section{DNA sequencing and homology search}

cDNA clones consist with up and down-regulated genes were subjected to PCR amplification using M13 universal primers. The vector $\mathrm{pDONR}^{\mathrm{TM}} 222$, which was used for the cDNA library construction contained M13 forward and reverse priming sites proximal to $a t t \mathrm{~L}_{1}$ and $a t t \mathrm{~L}_{2}$ regions, respectively. These amplified PCR products were sequenced and subjected to homology search using available DNA/Protein data bases (i.e. NCBI-BLAST and Esttik-BLAST-CIRAD) to predict putative genes and protein products of the cloned transcripts.

\section{Relative RT- PCR}

Relative RT-PCR was selected as a method of confirming gene expression (Dean et al., 2002; Chelly \& Kahn, 1994). RPS-2 gene was selected as an internal control for relative RTPCR as recommended by Chen et al., (2011) for gene expression studies of banana fruit. In addition to RPS-2, EBF-1 gene was also used to normalize the gene expression in banana fruit peel (Binder et al., 2007). One of the up-regulated gene transcripts, cloned in cDNA and designated as Ma SINI 1407 in the present study, was selected for confirmation of gene expression by relative RT-PCR. According to DNA sequencing and subsequent homology search, the transcript harboured by Ma SINI 1407 was identified as a gene homologous to Germin-Like-Protein (GLP) produced in Musa acuminata. Primer pair for amplifying cDNA fragment contained in Ma SINI 1407 clone was designed by Primer 3 software based on sequence information obtained for the gene transcript of Ma SINI 1407 in the present study. 
The base pair sequences of the forward and reverse primers were 5'TGCTTGTCCAAAGACAGTGC-3' and 5'- GCTTGTCTAAGCCGGTGAAG-3', respectively. The forward and reverse primers used for amplification of the internal control/reference gene of RPS-2 were 5'-TAGGGATTCCGACGATTTGTTT-3' and, 5'TAGCGTCATCATTGGCTGGGA-3', respectively and the forward and reverse primers used for amplification of the internal control/ reference gene of EBF-1 were 5'CCTCAATAAGCGATTACGGTG-3' and 5'- TCAGACTCCCAAGAGATTCC-3' respectively (Chen et al., 2011). The template cDNA having the same concentration for control and treated samples $(1000 \mathrm{ng} / \mu \mathrm{l})$ was used for the PCR amplification. PCR amplification was performed separately targeting the reference genes (i.e. RPS-2 and EBF-1) and Germin Like Protein Gene (GLP) homologue using cDNA samples prepared from inoculated and non-inoculated peel tissues collected at different time intervals after inoculation of $C$. musae as described earlier. PCR reaction conditions for the two reference genes (i.e. RPS-2 and EBF-1) and gene of interest (i.e. GLP) included an initial denaturation at $95{ }^{\circ} \mathrm{C}$ for $2 \mathrm{~min}$, denaturation at $95{ }^{\circ} \mathrm{C}$ for $30 \mathrm{sec}$, annealing at $60{ }^{0} \mathrm{C}$ for 30 seconds elongation at $72{ }^{\circ} \mathrm{C}$ for $2 \mathrm{~min}$ and final extension at $72{ }^{\circ} \mathrm{C}$ for $5 \mathrm{~min}$ with 40 reaction cycles. The expected sizes of the PCR products of RPS-2 and EBF-1 are $84 \mathrm{bp}$ and $280 \mathrm{bp}$, respectively.

\section{Analysis of RT-PCR products and quantification of relative gene expression of GLP gene homologue}

RT-PCR products were separated on $2 \%$ agarose gel and gel documentation was done by model Canon Utilities Zoom browser EX (Version 5.2 Copyright CANON INC 1996-2005). Gel photos were scanned and band intensity of each RT-PCR product was measured using an image digitizing software (Gel UN-Scan-IT software Silk Scientific Inc., USA). Relative GLP gene expression level was calculated by dividing the expression of gene of interest (i.e. GLP) by the expression of reference gene (RPS-2 or EBF-1) according to the method described by Dean et al. (2002). The relative intensity was determined based on the intensities of the reference gene and the gene of interest given by the gel image. The average pixel values for band intensities for the reference gene and the gene of interest were obtained by the Gel UN-SCAN-IT software.

\section{RESULTS AND DISCUSSION}

\section{Identification of differentially-expressed genes, responsive to $C$. musae infection in banana (cultivar Seenikesel)}

Identification of differentially-expressed genes was performed according to the intensity of the signal intensity on X-ray films (Fig. 1) after subjecting to the differential hybridization with treatment probes (inoculated with $C$. musae) and control probes (not-infected with $C$. musae). In the present study, 20 cDNA clones were identified and selected as up-regulated clones since they gave high signal intensities by treatment probe in comparison to the control probe. Differential hybridization resulted in 21 down-regulated cDNA clones which showed high signal intensities by control probe in comparison to treatment probe. However, focus in the present study was only on the up-regulated clones. 
(A)

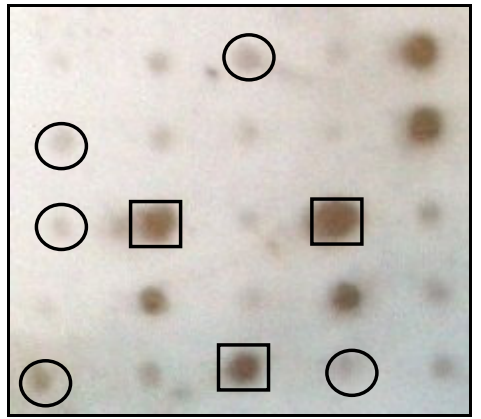

Hybridization with treatment probe
(B)

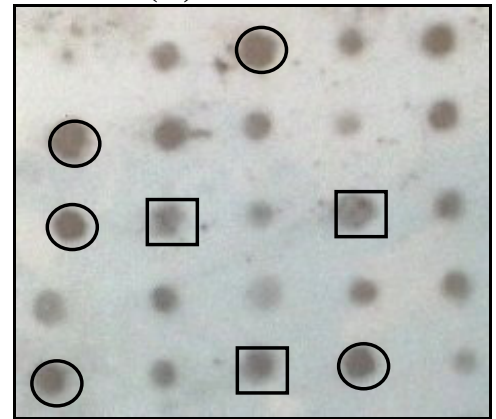

Hybridization with control probe

Fig. 1. Signals marked with $\square$ shape are up-regulated clones according to the signal intensity; signals marked with $\bigcirc$ shapes are down-regulated clones according to the signal intensity

\section{Analysis of DNA sequence of PCR products and homology search}

As depicted by the size of the PCR products, it was clear that the selected cDNA clones were carrying cDNA inserts of heterogeneous lengths (Fig. 2) which could be considered as a desirable feature of the cDNA library constructed in the present study.

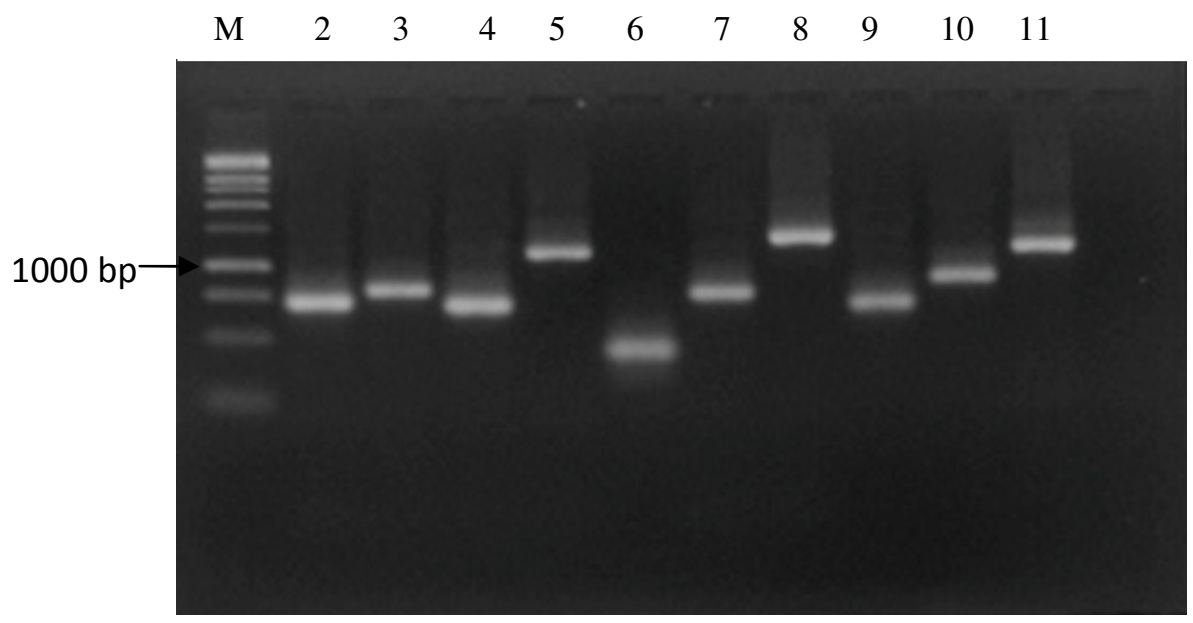

Fig. 2. PCR products amplified by M13 primers separated on $2 \%$ agarose gel and stained with Ethidium Bromide. Lane M: 1kb DNA size marker (Promega, USA), lanes 2-11: PCR products amplified from cDNA clones 1093, 1101, 1233, $1247,1259,1272,1336,1340,1354$ and 1407 , respectively.

Moreover, the cDNA inserts were larger than $500 \mathrm{bp}$. Therefore, these cDNA fragments were suitable for sequencing and subsequent homology search for identification of putative genes. The amplified PCR products were subjected to DNA sequencing (Macrogen, Korea) and homology search was done using available DNA databases to predict putative genes and protein products after vector screening by Vecscreen software (NCBI, USA). The sequence 
information for 20 cDNA clones were deposited in EMBL Gene Bank (EMBL Gene Bank, European Nucleotide Archive-ENA, EMBL-EBI, Wellcome Trust Genome Campus, Hinxton, Cambridgeshire, CB10 1SD, UK) according to the EMBL Gene Bank instructions. Accession numbers obtained for the sequences from EMBL Gene Bank are given in Table 1.

Table 1. DNA homology search results of the selected up-regulated genes in response to C. musae infection of banana (cultivar Seenikesel)

$\begin{array}{cccc}\text { cDNA } & \text { Gene/protein } & \text { Homologous host } & \begin{array}{c}\text { EMBL } \\ \text { accession } \\ \text { number }\end{array} \\ \text { Code } & \text { homology } & \text { Identity } & \text { E-value }\end{array}$

\begin{tabular}{|c|c|c|c|c|c|}
\hline $\begin{array}{l}\text { Ma SINI } \\
1093\end{array}$ & $\begin{array}{l}\text { Stress induced } \\
\text { proteins }\end{array}$ & Musa spp. (ABB) & HF567786 & $95.70 \%$ & $1.80 \mathrm{E}-46$ \\
\hline $\begin{array}{l}\text { Ma SINI } \\
1101\end{array}$ & $\begin{array}{l}\text { Stress induced } \\
\text { proteins }\end{array}$ & Musa spp. (ABB) & HF567787 & $99.80 \%$ & $3.70 \mathrm{E}-38$ \\
\hline $\begin{array}{l}\text { Ma SINI } \\
1233\end{array}$ & $\begin{array}{l}\text { Putative 2C- } \\
\text { methyl-D- } \\
\text { erythritol 2,4- } \\
\text { cyclodiphosphate } \\
\text { synthase }\end{array}$ & Ginkgo biloba & HF567788 & $81 \%$ & 7.00E-59 \\
\hline $\begin{array}{l}\text { Ma SINI } \\
1247\end{array}$ & Pectate lyase 1 & Musa acuminate & HF567789 & $94.20 \%$ & $7.60 \mathrm{E}-72$ \\
\hline $\begin{array}{l}\text { Ma SINI } \\
1259\end{array}$ & $\begin{array}{l}\text { Eukaryotic } \\
\text { elongation factor } \\
\text { 1A }\end{array}$ & $\begin{array}{l}\text { Bruguiera } \\
\text { sexangula }\end{array}$ & HF567790 & $97 \%$ & 0 \\
\hline $\begin{array}{l}\text { Ma SINI } \\
1272\end{array}$ & $\begin{array}{l}\text { Stress induced } \\
\text { protein }\end{array}$ & Musa spp. (ABB) & HF567791 & $96.90 \%$ & $7.30 \mathrm{E}-61$ \\
\hline $\begin{array}{l}\text { Ma SINI } \\
1336\end{array}$ & $\begin{array}{l}\text { Germin-like } \\
\text { protein }\end{array}$ & Musa acuminata & HF567793 & $94.1 \%$ & $3.00 \mathrm{E}-124$ \\
\hline $\begin{array}{l}\text { Ma SINI } \\
1340\end{array}$ & Aspartic protease & $\begin{array}{l}\text { Hordeum vulgare } \\
\text { sub spp. vulgare }\end{array}$ & HF567794 & $79 \%$ & $1.00 \mathrm{E}-126$ \\
\hline $\begin{array}{l}\text { Ma SINI } \\
1354\end{array}$ & â,1,3-Glucanase & Musa (ABB) & HF567797 & $95.40 \%$ & $2.80 \mathrm{E}-78$ \\
\hline $\begin{array}{l}\text { Ma SINI } \\
1407\end{array}$ & $\begin{array}{l}\text { Germin-like } \\
\text { protein }\end{array}$ & Musa acuminata & HF567801 & $94 \%$ & $6.00 \mathrm{E}-103$ \\
\hline
\end{tabular}

Homology search with available DNA/ Protein databases indicated that the EST sequence information were highly homologous with Musa genome with high percentage identities and E- values.

Fig. 3 illustrates the percentage composition of the up-regulated genes according to functional categories of the genes. 


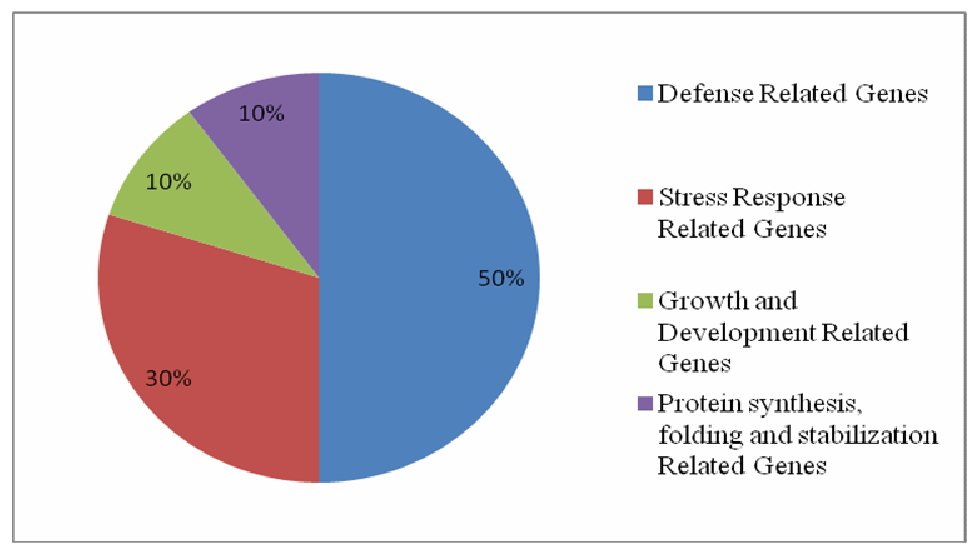

\section{Fig. 3. Percentage distribution of up-regulated gene transcripts based on functional categories}

Majority of the up-regulated transcripts identified (50\%) due to C. musae infection in banana cultivar Seenikesel belonged to defense related genes which are members of the general plant defense responses induced in many different plant-pathogen systems (Patricia et al., 2009). The second major group (30\%) of up-regulated transcripts were stress induced protein (SIP) related genes in Musa ABB genome. Moreover, some of the other up-regulated transcripts were homologous with growth and development related genes, and protein synthesis, folding and stabilization related genes (Fig. 3).

Transcripts $\beta-1,3$ glucanase mRNA complete DNA sequence (cds), GLP [Musa acuminata] and putative 2C-methyl-D-erythritol 2,4-cyclodiphosphate synthase and aspartic protease identified in the present study were categorized under the functional group of 'Defense'. Germins and GLPs participate in many processes that are important for plant development and defense (Patricia et al., 2009; Patnaik \& Khurana, 2001). Defense mechanisms also include production of lytic enzymes such as chitinases and $\beta-1,3$-glucanases which degrade chitin and glucan present in the cell wall of fungi (Attia et al., 2011). By degrading the cell wall it will reduce the growth of fungal hyphe of infecting fungal pathogens, within the host plant cell.

Stress induced proteins (SIPs) play a major role in defending plants from different stress conditions due to various biotic and abiotic stress factors. It is now well established that virtually all biotic and abiotic stresses induce or involved in oxidative stress to some degree, and the ability of plants to control oxidant levels is highly correlated with stress tolerance (Cheeseman, 2007). In contrast, growth and development related genes and protein synthesis, folding and stabilization related genes also mediate and enhance the plant defense mechanism to protect the plant against pathogenic invasions (Wegener et al., 1996). 


\section{Analysis of RT-PCR products and quantification of relative gene expression of GLP gene homologue}

RT-PCR amplification of the GLP gene homologue and reference gene (EBF-1) under inoculated and non-inoculated conditions after different inoculation time intervals are demonstrated by Fig. 4 .

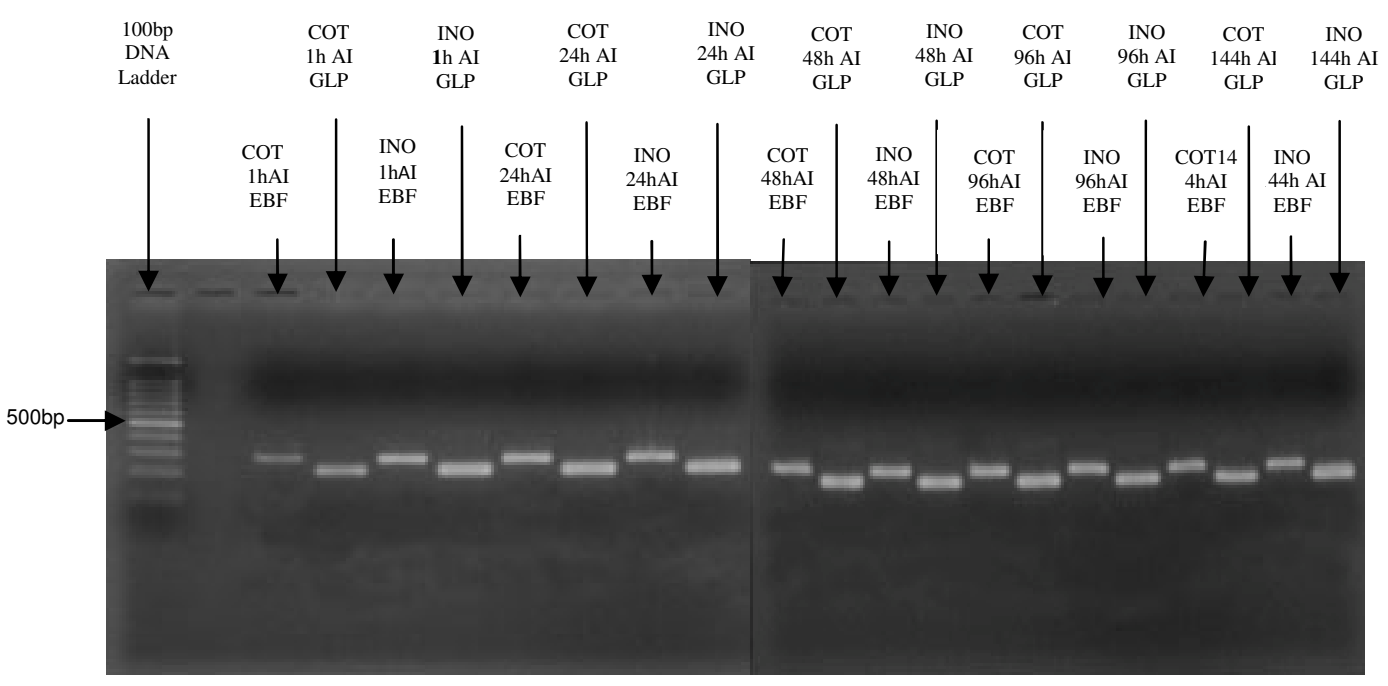

Fig. 4. RT-PCR amplified products of the GLP gene homologue and reference gene (EBF-1) under inoculated and non-inoculated (control) conditions after different time intervals of inoculation (COT= control (non-inoculated), INO= (inoculated with $C$. musae), $\mathrm{AI}=$ after inoculation)

The RPS -2 and EBF-1 genes were used to normalize the GLP gene expression in the present study. It is essential to normalize the gene expression analyzed by RT-PCR using one or more internal controller genes. RPS-2 gene was validated as the most suitable reference genes for RT-PCR analysis in banana (Chen et al., 2011). Relative gene expression of GLP gene at different time intervals were calculated based on EBF-1 and RPS-2 gene expression at each time interval after inoculation (Tables 3 and 4).

Table 3. Relative expression levels of homologous gene encoding Germin Like protein (GLP) under control and inoculated conditions at different time periods with reference to EBF-1 gene

\begin{tabular}{|c|c|c|c|c|c|c|}
\hline \multirow{2}{*}{$\begin{array}{l}\text { Time after } \\
\text { inoculation } \\
\text { (h) }\end{array}$} & \multicolumn{4}{|c|}{ Average pixel values } & \multicolumn{2}{|c|}{ Relative expression } \\
\hline & $\begin{array}{l}\text { EBF- 1 } \\
\text { gene } \\
\text { (control) }\end{array}$ & $\begin{array}{l}\text { EBF-1 } \\
\text { gene } \\
\text { (inoculated) }\end{array}$ & $\begin{array}{l}\text { GLP } \\
\text { homologue } \\
\text { (control) }\end{array}$ & $\begin{array}{l}\text { GLP } \\
\text { homologue } \\
\text { (inoculated) }\end{array}$ & $\begin{array}{l}\text { GLP } \\
\text { homologue } \\
\text { (control) }\end{array}$ & $\begin{array}{l}\text { GLP } \\
\text { homologue } \\
\text { (inoculated) }\end{array}$ \\
\hline 1 & 20.87 & 44.36 & 20.5 & 42.48 & 0.98 & 0.95 \\
\hline 24 & 47.92 & 46.78 & 41.83 & 41.55 & 0.87 & 0.88 \\
\hline 48 & 22.51 & 26.96 & 23.19 & 23.41 & 1.03 & 0.86 \\
\hline 96 & 28.04 & 24.34 & 14.88 & 11.5 & 0.53 & 0.47 \\
\hline 144 & 20.66 & 19.64 & 17.06 & 21.42 & 0.82 & 1.09 \\
\hline
\end{tabular}



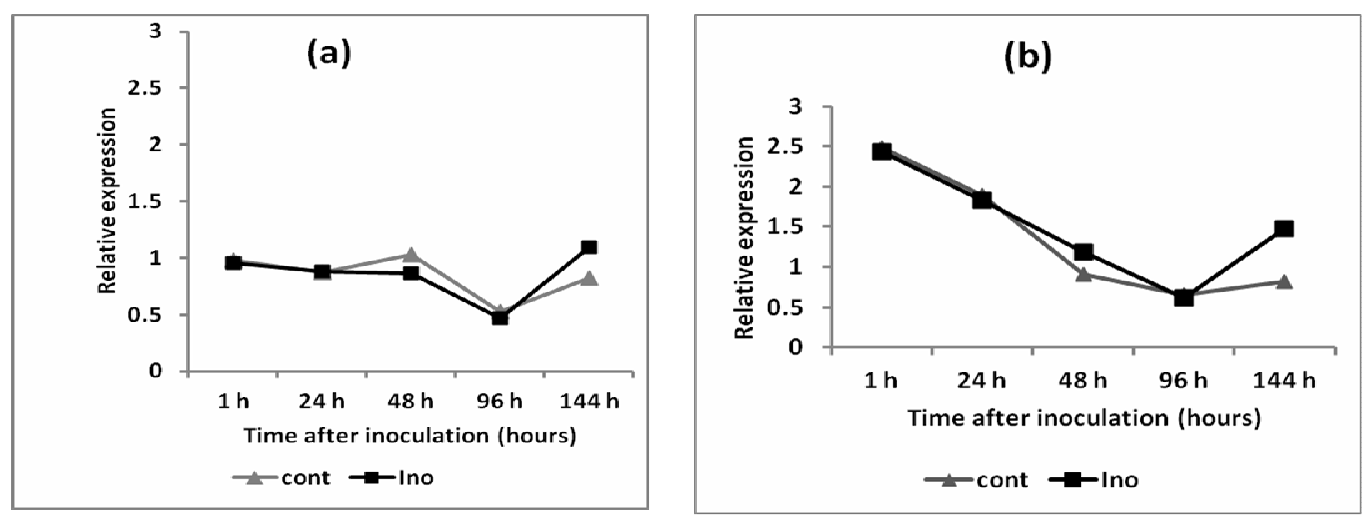

Fig. 5. Relative expression levels of Germin Like protein (GLP) gene homologue under control and inoculated conditions at different time periods with reference to, (a) EBF-1 and (b) RPS-2

Table 4. Relative expression levels of homologous gene encoding Germin Like protein (GLP) under control and inoculated conditions at different time periods with reference to RPS-2 gene

\begin{tabular}{ccccccc}
\hline $\begin{array}{l}\text { Time after } \\
\text { inoculation } \\
\text { (h) }\end{array}$ & \multicolumn{2}{l}{ Average pixel values } & & \multicolumn{2}{c}{ Relative expression } \\
\cline { 2 - 7 } & $\begin{array}{l}\text { RPS-2 } \\
\text { gene } \\
\text { (control) }\end{array}$ & $\begin{array}{l}\text { RPS-2 } \\
\text { gene } \\
\text { (inoculated) }\end{array}$ & $\begin{array}{l}\text { GLP } \\
\text { homologue } \\
\text { (control) }\end{array}$ & $\begin{array}{l}\text { GLP } \\
\text { homologue } \\
\text { (inoculated) }\end{array}$ & $\begin{array}{l}\text { GLP } \\
\text { homologue } \\
\text { (control) }\end{array}$ & $\begin{array}{l}\text { GLP } \\
\text { homologue } \\
\text { (inoculated) }\end{array}$ \\
\hline 1 & 8.26 & 17.47 & 20.5 & 42.48 & 2.48 & 2.43 \\
24 & 22.13 & 22.6 & 41.83 & 41.55 & 1.89 & 1.83 \\
48 & 25.26 & 19.63 & 23.19 & 23.41 & 0.91 & 1.19 \\
96 & 22.68 & 18.37 & 14.88 & 11.5 & 0.65 & 0.62 \\
144 & 20.78 & 14.49 & 17.06 & 21.42 & 0.82 & 1.47 \\
\hline
\end{tabular}

Based on relative RT-PCR analysis, it was clear that relative expression of GLP homologue was slightly equal to the relative expression of the GLP under non-inoculated conditions, especially at the early phase of infection. However, after a gradual decrease of the level of relative expression, a marked increase of the gene homologue could be identified in inoculated plants especially during the late phase of infection of C. musae (i.e. $96 \mathrm{~h}$ after inoculation) (Fig. 5).

Several research evidence suggest that GLPs are involved in general plant defense responses (Lane, 2002; Patnaik \& Khurana, 2001), including the observation that expression of certain GLPs is enhanced after infection with pathogens, feeding of insects, or application of chemicals such as salicylic acid, hydrogen peroxide $\left(\mathrm{H}_{2} \mathrm{O}_{2}\right)$, or ethylene (Zimmermann et al., 2006; Godfrey et al., 2007). Transient over expression of certain barley GLP subfamilies resulted in enhanced resistance to the powdery mildew fungus, and for some subfamilies, silencing resulted in enhanced susceptibility to the pathogen (Zimmermann et al., 2006). Accordingly, though GLP homologue is not the only reason for host plant resistance against anthracnose development in cultivar Seenikesel, it is clear that it could have a contributory 
effect on the lower spreading rate of the symptoms which is generally found in cultivar Seenikesel.

\section{CONCLUSION}

The present study identified 20 up-regulated and 21 down-regulated cDNA clones by differential hybridization of a cDNA library of banana (cultivar Seenikesel) infected with $C$. musae, the causal organism of anthracnose. Among the selected up-regulated cDNA clones, transcripts responsible for defense, stress response, growth, development, protein synthesis, protein folding and stabilization related genes were identified. Expression of GLP gene homologue (one of the defense related gene homologue) was comparatively higher in cultivar Seenikesel at the late phase of inoculation (96 h after inoculation) of C. musae.

\section{REFERENCES}

Abd-Elsalam, K.A., Roshdy, S., Amin, O.E. and Rabani, M. (2010). First morphogenetic identification of the fungal pathogen Colletotrichum musae (Phyllachoraceae) from imported bananas in Saudi Arabia. Genetics and Molecular Research. 9(4), 2335-2342.

Attia, M., Awad, N.M., Azza-Sh. and Hamed, T.H.A. (2011). Induction of defense responses in soybean plants against Macrophomina phaseolina by some strains of plant growth promoting rhizobacteria. Journal of Applied Sciences Research. 7(11), 1507-1517.

Binder, B.M., Walker, J.M., Gagne, J.M., Emborg, T.J., Hemmann, G., Bleecker, A.B. and Vierstra, R.D. (2007). The Arabidopsis EIN3 binding F-box proteins EBF1 and EBF2 have distinct but overlapping roles in ethylene signaling. The Plant Cell. 19(2), 509-523.

Cheeseman, J.M. (2007). Hydrogen peroxide and plant stress: a challenging relationship. Plant Stress. Global Science Books. 4-15.

Chelly, J. and Kahn, A. (1994). RT-PCR and mRNA quantitation. In: Mullis, D.B., Ferre, F. and Gibbs, R.A. (Eds), The Polymerase Chain Reaction. Birkhauser, Boston, MA. pp97-109.

Chen, L., Zhong, H., Kuang, J., Li, J., Lu, W. and Chen, J. (2011). Validation of reference genes for RT-qPCR studies of gene expression in banana fruit under different experimental conditions. Planta. 234, 377-390.

Dean, J.D., Goodwin, P.H. and Hsian, T. (2002). Comparison of relative RT-PCR and northern blot analyses to measure expression of -1, 3-Glucanase in Nicotiana benthamiana infected with Colltotrichum destructivum. Plant Molecular Biology Reporter. 20, 347-356.

De Costa, D.M. and Kalpage, M.D. (2006). Differential response of Colletotrichum isolates infecting banana to synthetic fungicide and a biological control agent. Sri Lankan Journal of Agricultural Sciences. 43, 50-65.

FAO Stat. (2007). [online]. [Accessed on 06.07.2012]. Available at http://faostat.fao.org/. htm. 
Godfrey, D., Able, A. and Dry, I. (2007). Induction of a grapevine germin-like protein (VvGLP3) gene is closely linked to the site of Erysiphe necator infection: a possible role in defense? Molecular Plant Microbe Interaction. 20, 1112-1125.

Hammond-Kosack, K.E. and Jones, J.D.G. (1996). Resistance gene-dependent plant defense responses. Plant Cell. 8, 1773-1791.

Kader, A.A. (2005). Banana: Recommendations for maintaining postharvest quality. [On line]. [Accessedon 06.02.2013]. Available at <http://postharvest.ucdavis.edu/Produce /ProduceFacts/Fruit/full_banana_ripening chart.shtml>.

Lane, B. (2002). Oxalate, germins, and higher-plant pathogens. IUBMB Life. 53, 67-75.

Lassois, L., Jijakli, M.H., Chillet, M. and de Lapeyre de Bellaire, L. (2010). Crown rot of banana- Pre harvest factors involve in postharvest disease development and integrated control methods. The American Phytopathological Society. Plant Disease. 94(6), 648-658.

Ma, B.C., Tang, W.L., Ma, L.Y., Li, L.L., Zhang, L.B. and Zhu, S.J. (2009). The role of chitinase gene expression in the defense of harvested banana against anthracnose disease. Journal of American Society of Horticultural Science. 134(3), 379-386.

Patnaik,D. and Khurana,P.(2001). Wheath Biotechnology: A minireview. Electronic Journal of Biotechnology ISSN:0717-3458.

Patricia, M., Manosalva, P.M., Davidson, R.M., Xiaoyuan- Zhu, B.L Hulbert, S.H., Leung, H. and Leach, J.E. (2009). A germin-like protein gene family functions as a complex quantitative trait locus conferring broad-spectrum disease resistance in rice. Plant Physiology. 149(1), 286-296.

Shibuya, N. and Minami, E. (2001). Oligosaccharide signalling for defence responses in plant. Physiological and Molecular Plant Pathology. 59, 223-233.

Wardlaw, C.W. (1934). The nature and occurrence of pitting diseases and fruit spots. Journal of Tropical Agriculture. 11, 8-13.

Wegener, C., Bartling, S., Olsen, O., Weber, J. and Wettstein, D. von (1996). Pectate lyase in transgenic potatoes confers pre-activation of defense against Erwinia carotovora. Physiological and Molecular Plant Pathology. 49(6), 359-376.

Zimmermann, G., Baumlein, H., Mock, H., Himmelbach, A. and Schweitzer, P. (2006). The multigene family encoding germin-like proteins of barley: regulation and function in basal host resistance. Plant Physiol. 142, 181-192. 